\title{
PENINGKATAN KINERJA BISNIS MELALUI STRATEGI PEMASARAN BERBASIS ONLINE PADA UKM PRODUK CAMILAN TRADISIONAL
}

\author{
Suryandari ISTIQOMAH ${ }^{1}$, Yeni FAJARYANTI2 ${ }^{2}$ Amina Sukma DEWI ${ }^{3}$ \\ Jurusan Manajemen, Fakultas Ekonomi dan Bisnis Universitas Sebelas Maret (UNS) \\ Email: suryandari.istiqomah@staff.uns.ac.id
}

\begin{abstract}
The internet is one of the technologies that is inevitable in today's digital era. One effect of the internet is also having an impact on the business world, among others, with the development of e-commerce and the decreasing number of offline retailers. therefore the use of internet / e-commerce as an alternative sale must be made by all entrepreneurs including traditional snack entrepreneurs.

This research aims to be able to help SMEs to introduce products through sales through the internet and its derivatives. In addition, this service also aims to introduce traditional snack products with better marketing strategies, including by using more eye catching packaging and selling so that they can be easily accepted by millennials.

This research has carried out several activities including operational training in marketing training on the importance of attractive brands and packaging, as well as online marketing. This service has helped provide assistance in making stickers, cardboard boxes and jars as a diversification of product packaging for UKM Kembang Goyang "Bu Ninik", Sragen. This dedication also initiates the use of gift boxes as a respondent to the beautiful appearance of souvenirs. In UKM Kumari Crispi, this research carried out by initiating product innovations with various flavors that are of interest to millennialsand providing shelter assistance for Kumari Crispy souvenir shops to support online businesses that will be run. All of training and accompaniment hope can improve the business performance of the target SMEs by increasing the demand for their products.
\end{abstract}

Keywords: Online Marketing, Innovation, Traditional Snacks

\section{ABSTRAK}

Internet merupakan salah satu teknologi yang tidak mungkin terelakan lagi di era digital saat ini. Salah satu efek dari adanya internet juga berdampak pada dunia bisnis antara lain dengan semakin berkembangnya e- commerce dan semakin menurunnya jumlah-jumlah retail offline. oleh karena itu penggunaan internet/ e-commerce sebagai alternatif penjualan harus dilakukan oleh semua pengusaha termasuk pengusaha camilan tradisional.

Pengabdian ini bertujuan untuk dapat membantu UKM untuk mengenalkan produk melalui penjualan lewat internet dan turunannya. selain itu pengabdian ini juga bertujuan untuk mengenalkan produk camilan tradisional dengan strategi pemasaran yang lebih baik antara lain dengan penggunaan kemasan yang lebih eye catching dan menjual sehingga dapat mudah diterima oleh generasi milenial.

Pengabdian ini telah melaksanakan beberapa kegiatan antara lain pelatihan operasional pelatihan pemasaran entang pentingnya merk dan kemasan menarik, serta pemasaran secara online. Pengabdian ini telah membantu melakukan pendampingan dalam pembuatan stiker, kardus dan toples sebagai diversifikasi kemasan produk kembang goyang. Pengabdian ini juga menginisiasi penggunaan 
kardus oleh-oleh sebagai pelanggap penampilan cantik rumah oleh-oleh yang dimiliki oleh UKM Kembang Goyang Bu Ninik, Sragen. Pada UKM Kumari Crispi pengabdian dilakukan dengan dengan 

menginisiasi inovasi produk dengan berbagai varian rasa yang diminati oleh generasi milenial serta pemberian bantuan rak untuk toko oleh-oleh Kumari Crispy untuk mendukung bisnis online yang akan dijalankan. Dengan pengabdian ini diharapkan dapat meningkatkan kinerja bisnis UKM binaan dengan semakin banyaknya permintaan produk mereka.

Kata Kunci: Pemasaran online, Inovasi, Camilan Tradisional

\section{PENDAHULUAN}

Pada era Gobalisasi, penggunaan internet sudah menjadi kebutuhan utama hampir setiap manusia. Kebutuhan internet digunakan manusia untuk memenuhi kebutuhan informasi, sosialisasi maupun digunakan untuk kepentingan bisnis. Secara keseluruhan, jumlah pengguna internet di seluruh dunia diproyeksikan bakal mencapai 3 miliar orang pada 2015. Tiga tahun setelahnya, pada 2018, diperkirakan sebanyak 3,6 miliar manusia di bumi bakal mengakses internet setidaknya sekali tiap satu bulan (kominfo.go.id). Pada 2017, eMarket memperkirakan netter Indonesia bakal mencapai 112 juta orang, mengalahkan Jepang di peringkat ke-5 yang pertumbuhan jumlah pengguna internetnya lebih lamban.

Memperkuat hal tersebut, Asosiasi Penyelenggara Jasa Internet Indonesia (APJII) setelah melakukan survei penetrasi dan perilaku pengguna internet di Indonesia menyebutkan jumlah pengguna internet tahun 2017 telah mencapai 143,26 juta jiwa atau setara dengan 54,68 persen dari total jumlah penduduk Indonesia. Jumlah tersebut menunjukan kenaikan sebesar 10,56 juta jiwa dari hasil survei pada tahun 2016. Hal ini dapat dilihat pada gambar. 1 berikut:

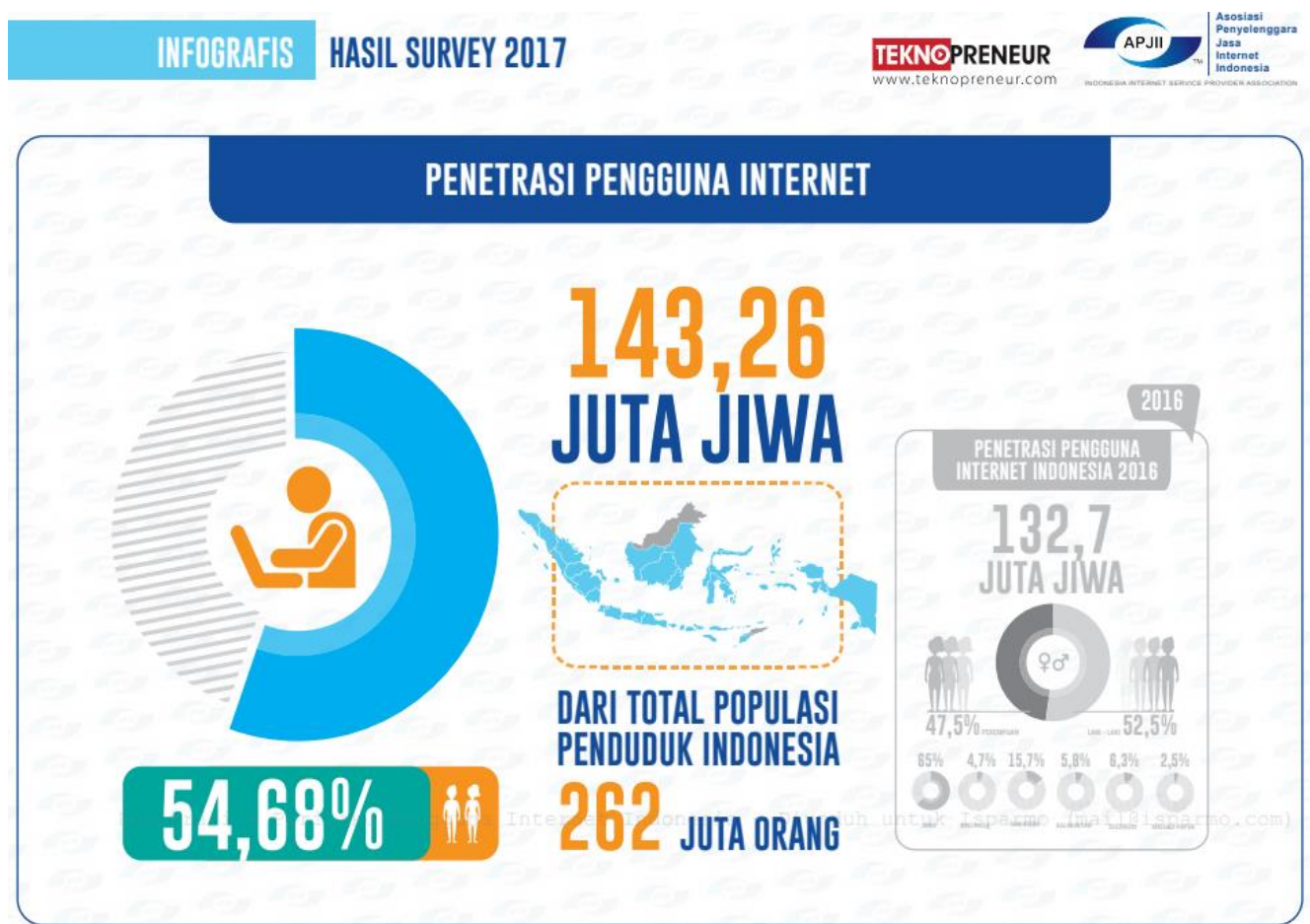

Gambar1. Jumlah pengguna internet di Indonesia Sumber: AAPJI (2017)

Perkembangan internet hari demi hari juga memberikan dampak terhadap perekonomian dan bisnis di dunia yaitu dengan banyaknya perdagangan melalui internet dan turunannya. Dampak lainnya adalah menurunnya jumlah perdagangan yang bersifat konvensional yaitu berupa retail-retail di seluruh dunia akibat semakin gencarnya perdagangan lewat internet. Perubahan ini juga mengharuskan semua jenis usaha berinovasi menyesuaikan dengan perubahan yang ada. 
Amabile et al. (1996) mendefinisikan inovasi sebagai implementasi dari ide yang kreatif dalam sebuah organisasi. Kemampuan organisasi dalam melakukan inovasi merupakan kunci untuk mendapatkan keunggulan kompetitif. Tidd, Bessant dan Pavitt (1997) menyatakan bahwa perusahaan yang memiliki keunggulan kompetitif adalah perusahaan yang mampu memobilisasi pengetahuan dan kemampuan teknologi serta pengalamannya untuk menciptakan sesuatu yang baru pada penawarannya (produk atau jasa), dan dalam bagaimana cara menciptakan dan menyampaikan penawaran tersebut. Inovasi yang dilakukan sebuah organisasi akan memberikan kontribusi dalam menciptakan produk baru yang mampu menangkap dan menguasai pangsa pasar, meningkatkan daya saing dalam hal waktu dimana perusahaan mampu menghasilkan dan mengenalkan produk baru lebih cepat daripada pesaing dan mampu mengganti produk dengan versi yang lebih baik secara berkala (Tidd, Bessant dan Pavitt, 1997).

Salah satu tipe inovasi yang dapat dilakukan oleh perusahaan untuk bertahan dalam bisnis adalah inovasi yang terkait dengan pemasaran adalah inovasi produk dan inovasi pasar. Secara umum, pemasaran adalah suatu proses sosial dan manajerial yang didalamnya individu dan kelompok mendapatkan apa yang mereka butuhkan dan inginkan dengan menciptakan, menawarkan dan mempertukarkan produk yang bernilai dengan pihak lain (Kottler, 1997). Pemasaran adalah sistem keseluruhan dari kegiatan usaha yang ditujukan untuk merencanakan, menentukan harga, mempromosikan dan mendistribusikan barang dan jasa yang dapat memuaskan kebutuhan kepada pembeli yang ada maupun pembeli potensial (Swastha,1996:10). Pengertian lain dari pemasaran adalah suatu proses sosial dan menejerial dimana individu atau kelompok mendapatkan apa yang mereka butuhkan dan inginkan melalui penciptaan, pewarnaan, dan pertukaran segala sesuatu yang bernilai dengan orang atau kelompok lain (Tjiptono, 2002). Sedangkan pemasaran dengan internet atau yang lebih dikenal dengan istilah e-commerce merupakan proses jual beli yang dilakukan melalui internet. Siregar (2010) menyatakan bahwa E- commerce adalah bagian dari e-business, dimanae business tidak hanya sekedar mengurusi masalah jula beli saja namun jua bagaimana pengkolaborasian mitra bisnis, menanggani pelayanan nasabah, supplier dan sebagainya. Zwass (1998) menyatakan bahawa e-commerce dapat dilihat dari tiga aspek yaitu perdagangan (commerce), fungsi bisnis (business) dan kerjasama (collaboration). Ecommerce melakukan pendekatan perniagaan melalui komputer dan jaringan internet memberikan manfaat yang sangat luas antara lain mempermudah komunikasi antara produsen dan konsumen yang selama ini mungkin tidak dapat terjangkau oleh pemasaran offline, memperluas pemasaran barang dan jasa, memperluasan jaringan pemasatan dan sebagainya (Wijaya et al., 2018). Dengan memanfaatkan perniagaan melalui ecommerce tersebut maka perusahaan dapat menjual produk dan jasa secara online tanpa harus harus memiliki toko atau kantor sehinngga dapat menekan biaya operasional yang dikeluarkan oleh perusahaan.

Melihat pentingnya e-commerce bagi perdagangan, maka hendaknya semua pedagang mampu menambahkan metode perdagangan mereka yang hanya dari sekedar berdagang offline ke perdagangan atau pemsaran online. Namun banyak usaha UKM di Indonesia yang belum bisa mengaplikasikan kecanggihan teknologi ini untuk memasarkan produk-produk mereka, sehingga mereka tidak bisa menikmati keuntungan dari produk yang mereka hasilkan. Hal ini juga merupakan salah satu kendala yang dihadapi oleh mitra binaan kami yaitu Kembang Goyang bu Ninik dan Keripik Usus Kumari Crispy. UKM Kembang Goyang "Bu Ninik" merupakan UKM pembuat camilan tradisional kembang goyang yang berada di Dusun Nglorog, Bulaksari, Sragen. UKM didirikan tahun 1998 oleh bu Ninik Ristiani untuk meningkatkan ekonomi keluarga setelah beliau resign sebagai agen asuransi. Dimulai dikenalkan sebagai hidangan arisan, PKK kampung menjadi UKM yang dikenal di masyarakat di sekitar Sragen. Walaupun telah berdiri sejak 20 tahun yang lalu namun kemasan produk masih sangat sederhana dimana merk yang diguakan hanya fotocopian kertas yang dimasukkan plastik kemasan. Selain itu pemasaran yang selama ini dilakukan hanya berada di rumah saja dan 2 toko di sekitar Sragen saja. Sedangkan UKM Kumari Crispy yang dimiliki oleh lbu Kumari berada di Desa Gonggangan, Bolon, Karanganyar merupakan UKM yang memproduksi keripik usus, keripik kulit ayam 
dan rambak kulit ayam. Penjualan produk ini sebenarnya sudah bagus dengan masuk ke beberapa toko oleh-oleh dan toko swalayan namun terdapat masalah atas kepemilikan merk yang selama ini digunakan yaitu merk "Annies" karena tidak hanya dimiliki oleh satu UKM saja. Oleh karena itu pemilik UKM ini berusaha melakukan rebranding merknya dengan mengeluarkan merk baru, dengan desain baru, kemasan baru agar dapat berkembang dengan lebih baik. Hal ini juga dikarenakan ijin P-IRT yang dimiliki oleh merk yang lama akan segera berakhir, sehingga dirasa saat ini saat yang tepat untuk mengeluarkan merk baru mereka. Adapun analisis situasi mitra binaan lebih detil disajikan dalam Tabel.1 sebagai berikut:

Tabel. 1 Uraian analisis situasi mitra binaan

\begin{tabular}{|c|c|c|}
\hline $\begin{array}{c}\text { Aspek Ekonomi dan } \\
\text { Bisnis UKM }\end{array}$ & Kembang Goyang Bu Ninik & $\begin{array}{l}\text { Kripik Usus } \\
\text { Kumari Crispy }\end{array}$ \\
\hline $\begin{array}{l}\text { 1. Latar Belakang } \\
\text { pemilik }\end{array}$ & $\begin{array}{l}\text { - Pemilik: Ibu Ninik Ristiani } \\
\text { merupakan ibu rumah tangga } \\
\text { dan suami pensiunan guru. } \\
\text { - } \text { Memulai bisnis kurang lebih } 20 \\
\text { tahun yang lalu digunakan } \\
\text { - Sebagai penyokong } \\
\text { perekonomian keluarga }\end{array}$ & $\begin{array}{l}\text { - Pemilik: Ibu Kumari, } \\
\text { merupakan salah satu PNS di } \\
\text { Kecamatan Colomadu, } \\
\text { Karanganyar dan suami } \\
\text { merupakan pensiunan TNI AU. } \\
\text { - } \text { Memulai bisnis keripik usus } \\
\text { dan keripik kulit ini kurang lebih } \\
\text { - } 3 \text { tahun yang lalu yang } \\
\text { merupakan hasil kerjasama } \\
\text { dengan rekan. }\end{array}$ \\
\hline $\begin{array}{l}\text { 2. Produk yang } \\
\text { dihasilkan dan } \\
\text { konsumen }\end{array}$ & $\begin{array}{l}\text { - Produk yang dihasilkan adalah } \\
\text { kembang goyang yaitu } \\
\text { makanan tradisional yang terbut } \\
\text { dari tepung, telur, santan dan } \\
\text { digoreng } \\
\text { - Produk mudah hancur } \\
\text { - Produk yang selama ini dibuat } \\
\text { dengan ukuran standar } \\
\text { - Dikemas dalam plastik } \\
\text { sederhana. } \\
\text { - Produk yang dihasilkan memiliki } \\
\text { rasa yang enak, renyah dan } \\
\text { gurih } \\
\text { - Merk yang dipake selama ini } \\
\text { hanya dari kertas putih yang } \\
\text { dicopi dan dimasukkan ke } \\
\text { dalam kemasan produk } \\
\text { - Konsumen dari kembang } \\
\text { goyang ini adalah konsumen } \\
\text { dari sekitar Sragen. } \\
\text { - Setiap beberapa hari sekali } \\
\text { produk diambil oleh sales yang } \\
\text { juga menyetorkan produk di } \\
\text { tempat Bu Ninik }\end{array}$ & $\begin{array}{l}\text { - Produk yang dihasilkan adalah } \\
\text { keripik usus, rambak kulit ayam } \\
\text { dan rambak kulit ayam. } \\
\text { - Produk yang sekarang telah } \\
\text { mempunyai P-IRT namun yang } \\
\text { menggunakan P-IRT ini tidak } \\
\text { hanya satu produk dari ibu } \\
\text { Kumari. } \\
\text { - P-IRT tersebut akan segera } \\
\text { habis masanya pada tahun } \\
\text { 2020, sedangkan P-IRT yang } \\
\text { baru diajukan oleh ibu Kumari } \\
\text { sendiri masih dalam proses } \\
\text { pengajuan. } \\
\text { - Produk yang sekarang dijual } \\
\text { untuk pengepul yang akan } \\
\text { menambil beberapa hari sekali } \\
\text { dan telah masuk ke beberapa } \\
\text { toko oleh-oleh terkenal di Solo. }\end{array}$ \\
\hline
\end{tabular}




\begin{tabular}{|c|c|c|}
\hline & $\begin{array}{l}\text { - Beberapa kali produk dipesan } \\
\text { oleh instansi pemerintah daerah } \\
\text { dan instansi lainnya yang } \\
\text { diberikan kepada tamu-tamu } \\
\text { dari luar Sragen yang dijadikan } \\
\text { sebagai oleh-oleh. } \\
\text { - Selain menjual kembang } \\
\text { goyang, di rumah juga sudah } \\
\text { terdapat barang-barang titipan } \\
\text { dari beberapa produsen kripik } \\
\text { yang ada di sekitar Sragen. }\end{array}$ & \\
\hline 3. Pemasaran & 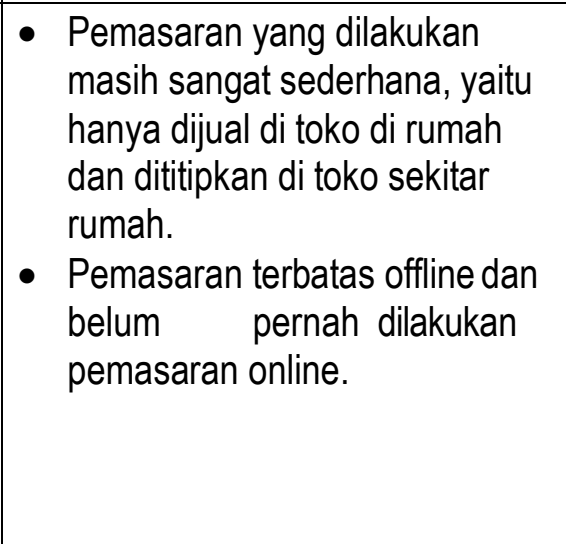 & $\begin{array}{l}\text { - Pemasaran yang dilakukan } \\
\text { melalui penjualan di rumah, } \\
\text { penitipan produk atau barang di } \\
\text { toko oleh-oleh sekitar Solo. } \\
\text { Penjualan tergantung dari } \\
\text { permintaan pelanggan sekitar } \\
\text { dan pelanggan dari toko oleh- } \\
\text { oleh } \\
\text { - Pemasaran terbatas offline dan } \\
\text { belum pernah dilakukan } \\
\text { pemasaran online. }\end{array}$ \\
\hline 4. Produksi & $\begin{array}{l}\text { - } \text { Alat produksi masih sangat } \\
\text { sederhana dan hanya satu alat } \\
\text { yang digunakan untuk } \\
\text { memproduksi kembang goyang } \\
\text { - Kompetensi dalam } \\
\text { memproduksi belum bisa } \\
\text { dturunkan kepada anggota } \\
\text { - } \text { keluarga yang lain }\end{array}$ & $\begin{array}{l}\text { - Produksi dilakukan di dapur } \\
\text { terbuka. } \\
\text { - Tempat pencucian bahan baku } \\
\text { hanya mengandalkan selang } \\
\text { dan tempat pembuangan yang } \\
\text { belum terstandar. }\end{array}$ \\
\hline
\end{tabular}




\section{Permasalahan Mitra}

Dari pertemuan awal atau survey pendahuluan yang telah dilakukan di UKM Kembang Goyang "Bu Ninik" di Bulaksari, Sragen dan UKM Kumari Crispy di Gonggangan, Bolon, Karanganyar diperoleh kesimpulan bahwa terdapat beberapa masalah yang dihadapi, yaitu antara lain:

\section{a. Produk}

UKM Kembang Goyang "Bu Ninik" memiliki masalah roduk kurang menarik karena kemasan yang digunakan sangat sederhana dan cenderung tidak menarik karena hanya menggunakan copian kertas putih yang dimasukkan ke dalam kemasan. Sedangkan untuk produk usus dari UKM Kumari Crispy yang ditawarkan masih relatif sama dengan produk competitor dengan rasa yang hamper sama, sehingga pasar yang ada sudah mulai jenuh dengan barang atau produk yang ditawarkan dan belum dapat menambah jumlah pasar yang lebih luas karena produk kurang bervariasi apalagi jika ingin meraih pasar sasaran konsumen milenial.

Hambatan:

- Produk yang dihasilkan satu jenis saja dan tidak ada inovasi produk

- Produk yang dihasilkan dikemas dalam kemasan yang sangat sederhana sehingga cenderung kurang menarik pelanggan

\section{b. Manajemen pemasaran}

Secara umum, strategi pemasaran yang dilakukan oleh UKM binaan adalah strategi pemasaran yang relatif masih sederhana, yaitu pemasaran getok tular, dan menggunakan media sosial yang sederhana, sehingga pemasaran belum terlalu luas. Selain itu UKM binaan juga merasa kesulitan mengenalkan produk mereka ke masyarakat luas karena terbatasnya dana untuk melalukan promosi.

Hambatan:

- Untuk UKM Usus belum memiliki toko offline yang representative untuk mendisplay produk- produknya untuk dapat dijual secara offline dan sebagai gambaran atau materi penjulan online

- Mitra binaan sulit untuk mengembangkan pasar mereka karena mereka belum memiliki media promosi yang efektif seperti instagram, facebook dan sebagainya.

- Para pengrajin belum memiliki kemampuan untuk membuat konten-konten pemasaran online

\section{c. Produksi}

Baik UKM Kembang Goyang "Bu Ninik" dan UKM Kumary Crispy memiliki permasalahan pada SDM yang membantu proses produksi. Masalah ini datang ketika karywan meminta ijin tidak masuk karena acara-acara kemasyarakatan yang ada dilingkungannya sehingga mengganggu proses produksi. Dari segi peralatan dan tempat produksi masih sangat sederhana dan cenderung kurang memadai.

\section{Hambatan:}

- secara umum mitra binaan banyak focus kepada produksi sehingga kurang memperhatikan pengembangan usaha yang lebih.

- UKM kesulitan mencari tenaga kerja untuk membantu mengembangkan usahanya maupun kesulitan untuk melarang karyawan ijin dalam kegiatan kemasyarakatan yang cukupsering

- Peralatan yang digunakan cenderung sangat sederhana dan temapt produksi kurang memadai Dari beberapa permasalahan diatas, pengabdi menawarkan beberapa solusi untuk memecahkan masalah tersebut, adalah sebagai berikut: 
Tabel 2. Permasalahan UMKM dan Solusi yang ditawarkan

\begin{tabular}{|c|c|c|}
\hline Permasalahan & $\begin{array}{l}\text { Permasalahan yang } \\
\text { akan diselesaikan }\end{array}$ & Solusi yang ditawarkan \\
\hline 1. Produk & $\begin{array}{l}\text { Produk yang } \\
\text { dihasilkan satu jenis } \\
\text { saja dan tidak ada } \\
\text { inovasi produk } \\
\text { - Produk yang } \\
\text { dihasilkan dikemas } \\
\text { dalam kemasan yang } \\
\text { sangat sederhana } \\
\text { sehingga cenderung } \\
\text { kurang menarik } \\
\text { pelanggan }\end{array}$ & $\begin{array}{l}\text { Mengembangkan beberapa model dan } \\
\text { variasi produk yang disesuaikan dengan } \\
\text { perkembangan dan keinginan konsumen. } \\
\text { Seperti membuat kemasan lebih eksklusif } \\
\text { untuk produk-produk UKM tersebut antara } \\
\text { lain dengan kemasan tople, paperclip dan } \\
\text { plastik dengan stiker. Sedangkan untuk } \\
\text { kembng goyang dapat dikemas dengan } \\
\text { kemasan kardus yang ekslusif yang dapat } \\
\text { masuk toko oleh-oleh } \\
\text { - Memperbanyak varian produk } \\
\text { dengan menambahkan berbagai rasa } \\
\text { seperti rasa bawang, } \\
\text { - keju, balado, BBQ dan sebagainya }\end{array}$ \\
\hline $\begin{array}{l}\text { 2. Manajemen } \\
\text { pemasaran }\end{array}$ & $\begin{array}{l}\text { - Pemasaran masih } \\
\text { dalam lingkup pada } \\
\text { lingkungan sekitar, } \\
\text { sehingga pemasaran } \\
\text { relatif stagnan. } \\
\text { - } \text { Belum optimalnya } \\
\text { strategi pemasaran } \\
\text { yang digunakan oleh } \\
\text { mitra binaan } \\
\text { - Kurangnya jejaring } \\
\text { karena minimnya dana } \\
\text { promosi } \\
\text { - Untuk UKM Usus } \\
\text { belum memiliki toko } \\
\text { offline } \\
\text { representative untuk } \\
\text { mendisplay produk- } \\
\text { produknya untuk } \\
\text { dapat dijual secara } \\
\text { offline dan sebagai } \\
\text { gambaran atau materi } \\
\text { penjulan online }\end{array}$ & $\begin{array}{l}\text { - Pembenahan manajemen pemasaran } \\
\text { dengan memperluas aspek pasar dengan } \\
\text { leafleat atau meningkatkan potensi } \\
\text { penggunaan promosi word of mouth dari } \\
\text { konsumen yang lain dan penggunaan media } \\
\text { sosial lainnya yang dapat digunakan untuk } \\
\text { memperluas pasar dan pasar potensial } \\
\text { - Pengenalan bauran pemasaran dan } \\
\text { strategi-strategi pemasaran (branding, } \\
\text { packaging, inovasi produk), standarisasi } \\
\text { produk untuk memperluas pasar melalui } \\
\text { pelatihan pemasaran kepada UKM } \\
\text { - Melakukan pengenalan dan pelatihan } \\
\text { pemasaran berbasis online kepada UKM } \\
\text { binaan } \\
\text { - Mengembangkan berbagai media sosial } \\
\text { memperkenalkan UKM melalui media-media } \\
\text { social yang ada seperti instagram, facebook } \\
\text { dan masuk ke marketplace } \\
\text { - Melakukan pendampingan dan penyiapan } \\
\text { materi- materi iklan yang digunakan untuk } \\
\text { memperkenalkan produk baik berupa konten } \\
\text { tulisan, foto maupun video. } \\
\text { - Membuat alamat di google map untuk } \\
\text { mempermudah melacak toko UKM } \\
\text { Membantu pembuatan toko offline agar } \\
\text { dapat lebih representative ketika membuka } \\
\text { toko online. }\end{array}$ \\
\hline
\end{tabular}




\begin{tabular}{|c|c|c|}
\hline $\begin{array}{l}\text { 3. Manajemen } \\
\text { Operasional }\end{array}$ & $\begin{array}{l}\text { - } \text { secara umum mitra } \\
\text { binaan banyak focus } \\
\text { kepada produksi } \\
\text { sehingga kurang } \\
\text { memperhatikan } \\
\text { pengembangan usaha } \\
\text { yang lebih. } \\
\text { - UKM kesulitan } \\
\text { mencari tenaga kerja } \\
\text { untuk membantu } \\
\text { mengembangkan } \\
\text { usahanya maupun } \\
\text { kesulitan untuk } \\
\text { melarang karyawan } \\
\text { ijin dalam kegiatan } \\
\text { - kemasyarakatan yang } \\
\text { cukup sering } \\
\text { Peralatan } \\
\text { yang digunakan } \\
\text { cenderung sangat } \\
\text { sederhana dan temapt } \\
\text { produksi kurang } \\
\text { memadai }\end{array}$ & $\begin{array}{l}\text { - memberikan pelatihan dan penjelasan } \\
\text { tentang manajemen sumberdaya manusia } \\
\text { mulai dengan metode prekrutan hingga } \\
\text { masalah kompensasi yang mungkin } \\
\text { diterapkan oleh UKM dengan pendekatan } \\
\text { kemanusiaan dan kearifan lokal. } \\
\text { - Menjelaskan kepada pemilik untuk mulai } \\
\text { dapat mengalihkan beberapa pekerjaan } \\
\text { operasional kepada karyawannya maupun } \\
\text { generasi penerus agar kedepannya dapat } \\
\text { meneruskan usaha tersebut. } \\
\text { - Memberikan bantuan peralatan kepada UKM } \\
\text { - Memberikan masukan layot kepada UKM } \\
\text { agar tempat produksi lebih bersih higienis } \\
\text { dan lebih representative. }\end{array}$ \\
\hline
\end{tabular}




\section{METODE PELAKSANAAN}

Secara garis besar metode yang akan digunakan dalam pengabdian ini dapat dilihat pada tabel sebagai berikut

\begin{tabular}{|c|c|}
\hline Implementasi IPTEK & Tahapan Pelaksanaan \\
\hline $\begin{array}{l}\text { Pelatihan Manajemen } \\
\text { Pemasaran dasar }\end{array}$ & $\begin{array}{l}\text { - Sebelum masuk kepada aksi tindakan, maka UKM binaan perlu } \\
\text { mendapatkan penjelasan melalui pelatihan tentang manajemen } \\
\text { pemasaran, yaitu menyangkut strategi pemasaran dengan } \\
\text { penekanan pada materi produk, kemasan, promosi } \\
\text { penetapan harga dan } \\
\text { sebagainya. }\end{array}$ \\
\hline $\begin{array}{l}\text { Pengembangan } \\
\text { kemasan }\end{array}$ & $\begin{array}{l}\text { - Diskusi dengan UKM tentang model packaging yang diinginkan } \\
\text { - Memberikan beberapa desain packaging yang menarik dengan } \\
\text { - } \text { Pemarna- warna yang mencolok untuk menggaet kalangan milenial } \\
\text { - Desain siap diperbanyak } \\
\text { - Uji coba dan penyempurnaan } \\
\text { - Untuk makanan kembang goyang dirancang dengan beberapa } \\
\text { kemasan antara lain dengan kemasan plastic yang telah diberikan } \\
\text { stiker, pengembangann kemasan kardus karena tipe makanan } \\
\text { kembang goyang yang sangat mudah remuk sehingga perlu } \\
\text { dikembangkan kemasan kardus, seta kemasan toples yang dapat } \\
\text { dipesan untuk hantaran acara-acara seperti pernikahan dan } \\
\text { sebagainya. } \\
\text { - Selain pengembangan kemasan primer untuk kembang goyang, } \\
\text { juga dikembangkan kemasan sekunder, mengingat usaha } \\
\text { kembang goyang Bu Ninik juga memiliki toko dengan beberapa } \\
\text { makanan setoran adri berbagai UKM di sekitar Sragen, sehingga } \\
\text { pengembangan kemasan sekunder ini akan semakin } \\
\text { mempercantik penampilan kemasan penjualan rumah oleh-oleh Bu } \\
\text { Ninik. } \\
\text { Khusus untuk packaging usus Kumari Crispy dikembangkan } \\
\text { dengan membuatkan berbagai stiker untuk produk yang } \\
\text { dikembangkan, yaitu keripik usus, keripik kulit ayam, dan rambak } \\
\text { kulit ayam dengan warna } \\
\text { yang berbeda untuk memudahkan saat penjualan dan menghindari } \\
\text { kesalahan dalam pengiriman barang. }\end{array}$ \\
\hline
\end{tabular}




\begin{tabular}{|c|c|}
\hline Pemasaran Online & $\begin{array}{l}\text { - Setelah packaging produk diperbaiki maka proses pemasaran } \\
\text { selanjutnya adalah memperkenalkan produk dengan menggunaan } \\
\text { berbagai media sosial yang menjadi tren saat ini } \\
\text { - Menyiapkan materi-materi iklan dengan bahasa yang persuasif } \\
\text { yang disesuaikan dengan materi-materi iklan "jaman now" } \\
\text { - Penyiapan materi iklan dalam bentuk video dan foto untuk } \\
\text { memberikan gambaran tentang produk camilan tradisional yang } \\
\text { akan dikenalkan ke kaum milenial } \\
\text { - Memperkenalkan usus dan kembang goyang sebagai camilan } \\
\text { tradisional } \\
\text { yang juga bisa bersaing dengan makanan-makanan jaman now }\end{array}$ \\
\hline $\begin{array}{l}\text { Inovasi Produk dan } \\
\text { Proses Produksi }\end{array}$ & $\begin{array}{l}\text { - Khusus untuk Usus Kumari Crispi, inovasi dilakukan dengan } \\
\text { memberikan berbagai varian rasa pada usus goreng, yaitu antara } \\
\text { lain rasa bawang, keju, balado dan BBQ dan sebagainya } \\
\text { - Khusus untuk kembang goyang, inovasi dilakukan dengan } \\
\text { membuat kembang goyang dalam ukuran yang lebih mini sehingga } \\
\text { dapat dijual dengan harga yang lebih bersahabat dan semakin } \\
\text { cocok untuk dapat masuk sebagai kategori oleh-oleh } \\
\text { - Mencobakan alat-alat baru yang dapat mempercepat proses } \\
\text { produksi kembang goyang } \\
\text { - Memberikan masukan tentang bagaimana layout produksi dan } \\
\text { layout pengembangan toko bagi UKM Kumari Crispi } \\
\text { - Memberikan bantuan rak untuk menatahasil produksi yang } \\
\text { diharapkan } \\
\text { dapat memperluas pemasaran usus Kumari Crispy }\end{array}$ \\
\hline
\end{tabular}

Selain metode pelaksanaan di atas, pengabdian ini juga memberikan pendampingan dengan memantau perkembangan UKM dilakukan dengan cara mendengarkan keluhan dan permasalahan yang dihadapi oleh UKM mitra binaan. Tim Pengabdii memberikan masukan dan solusi atas permasalahan yang telah dikemukakan sebelumnya. Proses pendampingan akan dilakukan intensif kepada UKM mitra binaan antara lain dalam pengembangan pembuatan merk, kemasan, pembuatan materi iklan, permasalahan yang dihadapi pemasaran online dan sebagainya. Hal ini diperlukan untuk melihat progress dan perkembangan kinerja UKM mitra binaan dari waktu ke waktu. Proses pendampingan intensif ini diharapkan dapat memaksimalkan program pelatihan yang telah diberikan di awal, sehingga dapat memberikan hasil yang maksimal. Proses pendampingan ini diharapkan terjalin komunikasi yang berkelanjutan antara UKM mitra binaan dengan pendamping. 


\section{PELAKSANAAN PENGABDIAN}

Pelatihan awal yang diberikan kepada UKM Kembang Goyang "Bu Ninik" adalah pelatihan operasinal. Pelatihan ini dilakukan dengan cara pencobaan alat cetak baru yang telah dibelikan oleh tim pengabdi sebelumnya untuk dapat mempercepat proses produksi yang selama ini mengandalkan satu alat saja. Pelatihan selanjutnya yang dilakukan adalah pelatihan pemasaran. Pelatihan ini dilakukan dengan Focus Group Discussion (FGD) dengan pemilik usaha, menanyakan kegiatan sehari-hari seperti apa, kemudian tim pengabdi baru menyisipkan penjelasan tentang pentingnya strategi pemasaran untuk pemasaran produknya. Salah satu bahasan yang ditekankan oleh tim pengabdi adalah bahwa kemasan yang menarik akan dapat meningkatkan nilai produk dimata konsumen. Selain mengenai kemasan tim pengabdi juga memberikan penjelasan tentang promosi, inovasi, penetapan harga dan sebagainya. Tim pengabdi kemudian mencatat hal-hal pokok apa saja yang sebaiknya ditingkatkan dari unsur pemasaran dari UKM binaan. Khusus untuk UKM binaan kembang goyang, secara pelayanan kepada pelanggan sudah baik, namun secara kemasan produk menjadi salah satu hal yang harus diperbaiki untuk dapat meningkatkan kinerja bisnisnya. Kemudian tim engabdi juga memberikan masukan tentang adanya inovasi penjualan melalui berbagai varian kemasan yang bisa digunakan di UKM kembang goyang Bu Ninik seperti terlihat dalam gambar 2. Sedangkan bagi UKM Kumari Crispy, tim pengabdi membantu penyusunan dalam stiker baru yang dikembangkan untuk produk yang akan dijual secara online. Hal ini dilakukan karena P-IRT dalam kemasan sebelumnya agak menjadi masalah dan sudah akan habis ijinnya, sedangkan ijin P-IRT yang baru masih dalam pengurusan. Dalam penyusunan stiker baru ini disesuaikan konsep baru yang akan diusung untuk penjualan online. Salah satu konsep baru yang diusung adalah dengan memberikan inovasi produk dengan cara penambahan rasa-rasa seperti rasa pedasa, balado, keju dan sebagainya. Adapun materi stiker untuk Kumari Crispy dapat dilihat pada gambar. 3 .

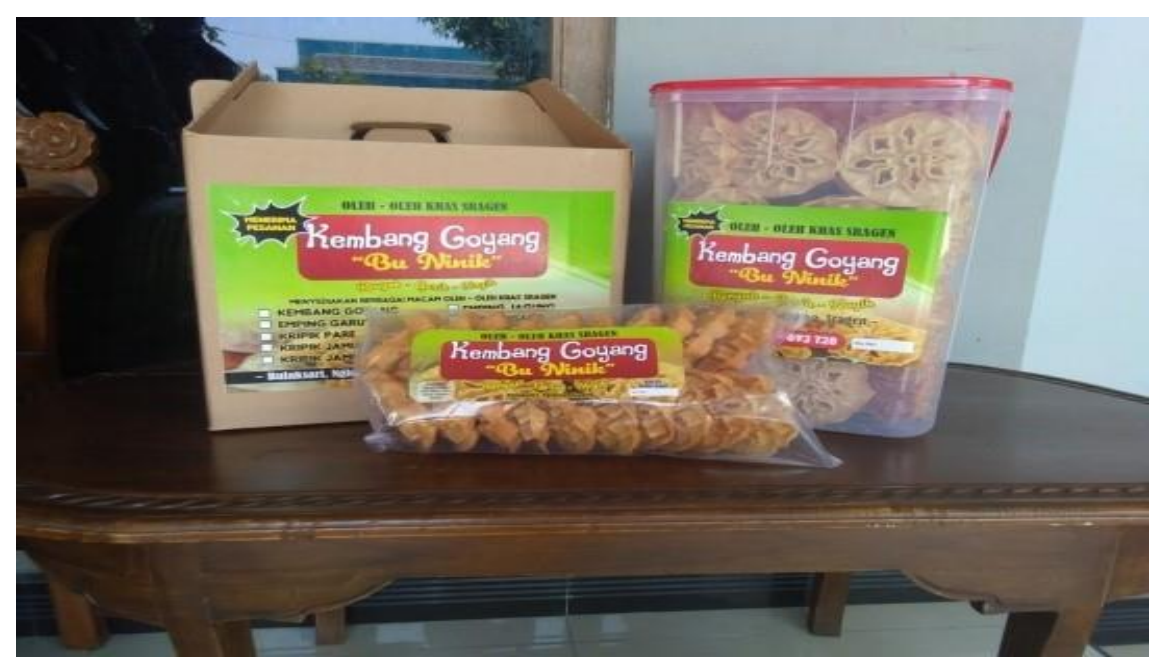

Gambar 2. Varian kemasan Kembang Goyang Bu Ninik Sumber: Dokumentasi Pengabdi (2019) 

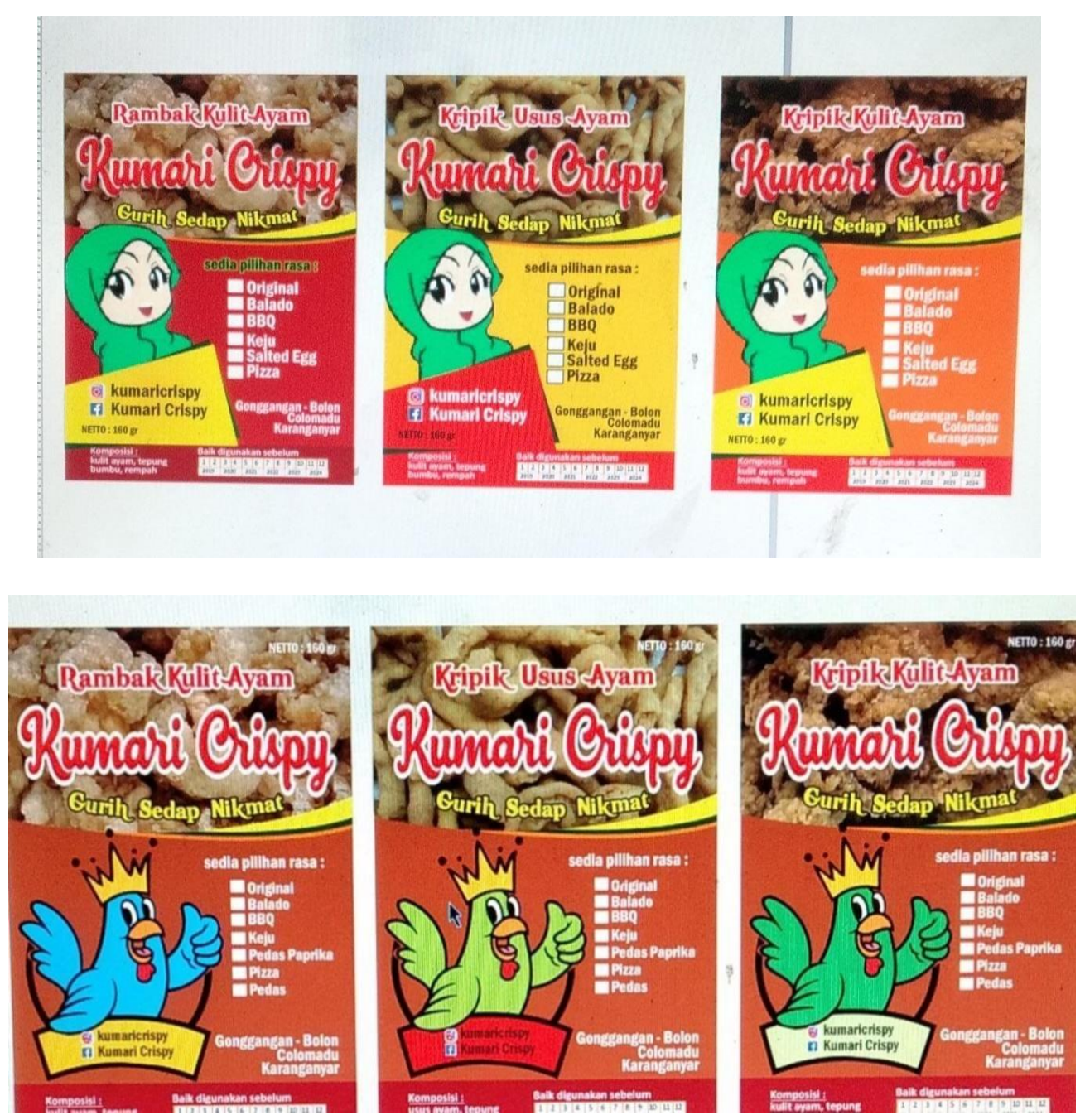

\section{Gambar 3. Materi Stiker untuk Kemasan Kumary Crispy Sumber: Dokumentasi Pengabdi (2019)}

Setelah dari pelatihan pemasaran tersebut, komunikasi selalu dilakukan dengan UKM dalam penyusunan stiker maupun penyusunan konsep kemasan yang akan digunakan oleh UKM binaan, seperti dalam pemilihan konsep stiker yang akan dipake selalu dikomunikasikan dengan UKM binaan. Setelah

mencetak stiker dan kemasan yang baik maka proses selanjutnya memberikan pelatihan pemasaran online. Pelatihan pemasaran online dimulai dengan mamberikan penjelasan pentingnya pemasaran online kepada UKM binaan termasuk memberikan contoh sukses yang telah didapatkan beberapa UKM yang telah melakukan pemasaran online. Tahap selanjutnya adalah memberikan pelatihan pengambilan gambar-gambar untuk konten pemasaran online. Pelatihan ini dilakukan dengan cara pemberian contoh penataan bara, pengambilan angle-angle yang baik dengan kamera HP yang ada. Setelah itu dilanjutkan dengan simulasi pengambilan gambar yang dilakukan oleh UKM Binaan. Pelatihan dilanjutkan dengan memberikan contoh materi cara melakukan persuasi di media sosial yaitu penyusunan kata-kata yang menyertai gambar yang akan diupload di media sosial. Setelah mendapatkan berbagai materi, kemudian UKM binaan diminta untuk membuat dan mempraktekkan pemasaran mereka di Intagram dan facebook seperti terlihat pada gambar 4. 


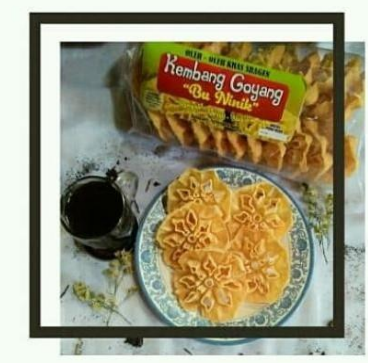

\section{Kembang Goyang}

Oleh-oleh Khas Sragen

Renyah - Gurih - Nagih

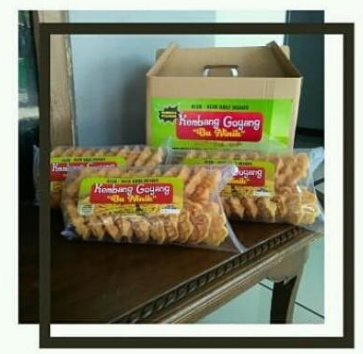

\author{
○ $\nabla$ ๑ \\ 3 suka \\ buninik.kembanggoyang Hallo kembang goyang \\ lovers $s$ \\ Yang ditunggu tunggu hadir juga nih $=$ \\ Apa sih kembang goyang itu? \\ Yapp, kembang goyang adalah camilan tradisional \\ yang berbahan dasar tepung terigu, nama \\ kembang goyang berasal dari bentuk camilan ini yg \\ menyerupai kelopak bunga atau kembang , dan \\ cara membuatnya dengan menggunakan cetakan \\ yang digoyang goyangkan sehingga dinamakan \\ kembang goyang $*$ \\ Sudah tahu belum rasa dari kembang goyang ini yg \\ Renyah dan Gurih yang pasti akan bikin kamu \\ ketagihan, mau lagi... lagi... dan lagi... \\ Kembang Goyang ini bisa dibeli dimana? \\ Jangan khawatir kembang goyang ini bisa \\ didapatkan di Bulaksari, Nglrog, Sragen \\ Yang kepo dan pengen order bisa chat via wa \\ ataupun telp: $\rightarrow 085642014895$ \\ \& (0271) 893728 \\ \#kulinersragen \#camilantradisional \#sragenhits \\ \#sragenkuliner \#sragen \#sragenasri \#kulinersolo \\ \#ilatsolo \#jelajahsolo \#solo \#camilansoloraya \\ \#camilankekinian \\ 44 menit yona lalu
}

\section{Gambar 4. Contoh Pemasaran Online Sumber: Dokumentasi Pengabdi (2019)}

Dari berbagai pelatihan dan pendampingan yang telah dilakukan kepada UKM elah didapatkan hasil bahwa dengan pemasaran online dapat merambah pasar baru yang selama ini belum kenal dengan produk UKM tersebut. Hal ini dibuktikan dengan banyaknya pertanyaan yang masuk setelah diuploadnya materi-materi diberbagai media social. Dari beberapa penanya ada yang tertarik untuk membeli barang dan atau menjadi reseller dari produk tersebut. Dari beberapa konsumen yang telah mencoba produk memberikan tanggapan yang positif, namun diperlukan waktu yang lebih lama untuk melihat perkembangan dari pemasaran online yang telah dilakukan sehingga dapat mendapatkan hasil yang lebih optimal.

\section{SIMPULAN}

Inovasi merupakan suatu hal yang harus dilakukan oleh perusahaan baik besar maupun kecil untuk tetap dapat bertahan untuk menghadapai perubahan dan perkembangan tekologi. Inovasi tersebut dapat dilakukan melalui invovasi produk, proses, maupun pemasaran. UKM camilan tradisionalpun harus melakukan inovasi untuk menghadapi persaingan yang memunculkan produk-produk baru dengan kesan modern. Inovasi dapat dilakukan dengan cara memperbaiki tampilan produk agar terlihat lebih enak dilihat atau dengan melakukan inovasi pemasaran mereka melalui berbagai media social yang ada sehingga dapat terus bertahan dan meningkatkan usaha mereka. 


\section{REFERENSI}

Amabile, T. M. (1996). Creativity in context: Update to "The Social Psychology of Creativity". Boulder, CO: Westview Press.

Kotler, Philip. 1997. Manajemen Pemasaran: Anaisis, Perencanaan, Implementasi dan Kontrol. Jakarta: Salemba Empat.

Swastha, Basu. 1996. Azas-Azas Marketing. Yogyakarta: Liberty.

Siregar R.R. 2010. Strategi Meningkatkan Persaingan Bisnis Perusahaan dengan Penerapan eCommerce. http://blog.trisakti.ac.id.

Tidd J, Bessan J, Pavitt, K. 2005. Managing Innovation Integrating Technological, Market, and Organization Change. Ed ke-3. Inggris (GB): John Wiley \& Sons, Ltd.

Tjiptono, Fandy. 2008. Strategi Pemasaran. Edisi V. Yogyakarta: Andi Offset.

Wijaya, R., Farida, N., \& Andriyansah. (2018). Determinants of repurchase intentions at online stores in Indonesia. International Journal of E-Business Research, 14(3), 95-111. https://doi.org/10.4018/IJEBR.2018070106

Zwass, V., 1998, Foundation of Information Systems, International Edition, McGraw- Hill, USA. https://kominfo.go.id/content/detail/4286/pengguna-internet-indonesia-nomor-enamdunia/0/sorotan media 